\title{
Higher Education Reforms in Malawi with Specific Reference to Equitable Access
}

\author{
Beaton Galafa ${ }^{1}$ \\ ${ }^{1}$ College of Teacher Education, Zhejiang Normal University, People's Republic of China [E- \\ mail: beatongalafa@gmail.com]
}

\begin{abstract}
This paper discusses the re-adoption of equitable access to higher education policy as one of the most controversial reforms in public university education in Malawi. It reviews the origins of the policy as a means of redressing disparities in access to higher education and the debates that have continuously ensued between the policy's proponents and opponents. The paper also discusses the concept of equitable access to higher education and how it has evolved from the notion of quota system. Through the debates, the paper offers insights into the benefits of the system as well as its challenges. It also reviews possible long- and short-term solutions to addressing the issues of access to higher education.
\end{abstract}

Keywords: Access; Equity; Reform.

\section{$1 \quad$ Introduction}

Access to higher education is very critical in Malawi. Currently, there are only four public universities namely The University of Malawi (UNIMA), Mzuzu University (MZUNI), Malawi University of Science and Technology (MUST), and Lilongwe University of Agriculture and Natural Resources (LUANAR). This is against a population of around 18 million people in the country. As such, access to the public universities is very limited due to space availability. In 2008, public universities in Malawi admitted only $0.03 \%$ of the eligible students (Chawinga \& Zozie, 2016). Msiska (2016) notes that although students' enrolment reports in the public universities vary with different sources, the underlying fact remains that in all cases, the sources point to terribly low enrolment rates. For instance, Msiska's study notes that the World Bank (2010) puts the figure at $0.3 \%$, the Southern African Regional Universities Association (2009) puts it at 1\% while $\mathrm{Ng}$ 'ambi (2010) indicates that only $0.6 \%$ of those eligible are actually enrolled 
(Msiska , 2016). Sharra (2012) also observes that out of 102651 students who sat for the 2011 Malawi School Certificate of Education (MSCE) examinations, only 908 students were enrolled in the University of Malawi, which remains the biggest public university in terms of intake numbers in the country. This was out of a total of 8507 candidates who had sat for the 2012 University Entrance Examinations (UEE) out of which 6373 passed, representing a $75 \%$ pass rate (Sharra, 2012). For LUANAR, which based its selection on the same students who had applied to the University of Malawi, 456 students were admitted. In the same year, Mzuzu University whose admission system was different from that of the other two public universities enrolled 366 generic students. For the university, a total of 6,217 candidates applied for admission into the University. Out of these applicants 5,161 qualified for entry into the programmes they had applied for while 1,056 did not qualify. Mzuni never administered university entrance examinations - it used the candidates' performance at Malawi School Certificate of Education (MSCE) or its equivalent as the academic basis for merit ranking of candidates (Mzuzu University, 2012). This demonstrates how a large percentage of candidates who had qualified for admission were left out because of limited space. A combination of these statistics renders Malawi one of the poorest ranking countries in the world in terms of access to higher education, creating the basis for swift reforms and interventionist approaches guiding the limited access.

Admission into public universities in the country has often taken various forms. Initially, there was only one public university in existence - The University of Malawi - founded in 1964 (Msiska, 2015). With the initial enrolment consisting of a total of just 90 students in 1965 (Valeta, Sefasi, \& Kalizang'oma, 2016), admission into the university was based on candidates' performance in the MSCE examinations in secondary school conducted by the Malawi National Examinations Board. However, government modified the admission policy, citing inequalities in access to university education within the public university system. This was a result of the pattern of colonial education which saw Malawians from the north accounting for many of the most senior positions in education and the civil service (Carver, 1994). The government therefore repeatedly took administrative measures to try to reverse the imbalance. This marked the introduction of the university Quota System in the regime of the country's first postcolonial president, Dr. Hastings Kamuzu Banda. A regional Quota System was first introduced in 1969 (Carver, 1994). In 1987 a more stringent district Quota System replaced the regional system. The main reason for the introduction of the policy was a perceived regional underrepresentation in the university. However, the system was outlawed in 1993 by the High Court of Malawi (University World News, 2010). The court argued that the policy 'was discriminatory and in violation of the fundamental right of Malawian citizens to 
equitable development through equal opportunities to access higher education, regardless of one's district or region of origin or ethnicity'(Manyukwe, 2008).

In 2009, the release of University Entrance Examination (UEE) results suffered a prolonged delay resulting from a court case that had been filed by two concerned members of the public against Council of the University of Malawi. The concerned parties argued against the re-adoption of the Quota System under the new banner 'Equitable Access to Higher Education'. Popularly termed Quota System in public discourses, the policy was re-introduced following a re-iteration of the sentiments that had led to its introduction in 1969 and the subsequent tightening up in 1987. Government cited the same regional underrepresentation in university enrolment as the cause for the policy's re-adoption, with the purpose of ensuring that each of the country's 30 districts had specific allocation of slots for students' enrolment in public universities. This was despite an order by the High Court in 2008 barring the University of Malawi from implementation of the policy (Manyukwe, 2008). In defence of the reform, government argued through public broadcasters and interviews on various forums that the reform was not targeting people from a specific region; rather it was aimed at giving every Malawian equal opportunity to university education. The University Council in 2009 won the case, marking the actual re-adoption of the system, with the 2010 UNIMA cohort being selected on this new basis.

\section{$2 \quad$ Related Literature}

Quota System is not a strange phenomenon in discourses relating to access to higher education around the world. As an affirmative action, it has been deployed by various governments globally as a means of redressing social injustice manifested in the underrepresentation of certain groups of people in institutions of higher learning. The historical background of racial discrimination in countries like the United States of America and Brazil, as well as the caste systems of India has often led to the need for affirmative action in university admissions. In the United States, racial quotas in students' admission to university have been in existence since the 1960s when President John F. Kennedy created the Council on Equal Opportunities in 1961 from which the policy evolved (CNN, 2018). The history of racial discrimination and the subsequent denial of education of the country's Hispanic and Africa Americans form the social basis for the implementation of the Quota System (Sabbagh, 2011).

Although it might appear as straightforward that the policy is a necessity given its justification, Moran (2006) notes that affirmative action in the United States remains contentious. The race-conscious admissions have been subject to lawsuits since the 1970s. The 1980s and 1990s saw some twists as the debate 
intensified, with lower federal courts starting to reach remarkably different conclusions about the constitutionality of considering race and ethnicity to achieve diversity in the student body (Moran, 2006). Complaints about reverse discrimination and racial quotas from white applicants have been at the centrestage in these court cases, leading into a ban of the policy in eight states, among them California, Oklahoma and Florida (Desilver, 2014). However, such bans have normally been followed by other affirmative action measures in recognition of the disparities. While admitting that the use of affirmative action programs in college admissions has roiled campuses and the public for years, leading to the aforementioned state-passed laws banning the practice, a 2014 survey by Pew Research Centre found that Americans overwhelmingly support affirmative action. According to the survey, 'Americans say by roughly two-to-one (63\% to $30 \%$ ) that affirmative action programs designed to increase the number of black and minority students on college campuses are a "good thing," according to the survey conducted in 2016,' almost the same result Pew Research found in a similar survey in 2003(Drake, 2014).

Similarly, racial discrimination has also led to the introduction of Quota System in university admission in Brazil. In the country, affirmative action policies for entrance into higher education have been put in place since 2001 (Telle \& Paixão, 2013). However, the policies have also stirred controversy, attracted criticism and undergone juridical dispute precisely on account of the forms of classification they employ (Brandão \& Marins, 2007). Previously, entry into university was based solely on merit - a process which favoured whites because of their socio-economic background emanating from the country's historical context again (Andrade, 2004). Following this system, a study by Santos and Queiroz (2016) notes that 'the majority of students who enrolled in majors of high prestige and status, like Medicine, Architecture, Law, Odontology, Engineering and Psychology, were white students from the middle class with high incomes, who attended private schools and whose mothers or fathers had higher education'. Demonstrating the inequity in admission at the Federal University of Bahai, the study also observes that non-white students for example fell short of $10 \%$ of the offered spaces with a reported non-existence of indigenous students in the university and the percentage of students from public schools failing to reach $20 \%$ in the prestige majors (Santos \& Queiroz, 2016).

In India, government instituted reservation policies or quotas to redress injustices and create systems that foster equal opportunity in Indian education in 1982 (Bhattacharyya, Woods \& Lykes, 2017). However, Quota System in university admission is also a highly contentious policy. Deshpande (2012) cites three main reasons for this. Firstly, there is disagreement over the assessment of caste disparities. Some quarters argue that even if there were disparities, they would not be significant enough to warrant affirmative action in access to higher education. The discourse also tends to question the extent and sphere of the 
disparities and a possible review of state of affairs (Deshpande, 2012). The second question in the contention is on whether caste is a valid indicator of backwardness and whether affirmative action must be perceived in terms of class/income or other social markers such as religion. The last aspect of the debate is on whether affirmative action is an appropriate intervention measure at all that it can successfully redress the problems of inequity in access to higher education perpetrated by the caste system (Deshpande, 2012). The Gross Enrolment Ratio in higher education in India exposes caste variations, with the lower castes having a consistent underrepresentation in the country's higher education system. Further, in all caste groups, urban participation rates are consistently higher than rural rates and gaps have widened over time (Deshpande, 2012).

In Malawi however, the affirmative action in admission into public universities is neither a result of racial discrimination nor the caste system. The background to the introduction of the Equitable Access to Education has been regional underrepresentation. A few scholars have conducted studies and written on the system, mostly on its negatives in a multi-ethnic country like Malawi. Carver (1994) attributes the conception of the Quota System to colonial legacy. He argues that due to the pattern of colonial education, Malawians from the northern region have accounted for many of the most senior positions in education and the civil service. This is in line with the argument by Michael (1978) who posits that the northern region had longer and more deeply rooted traditions of educational interest and achievements than the rest of the population resulting from a set of complex historical, cultural and geographical reasons (Chivwara, 2013). Kapito (2016) agrees with the reasoning behind the readoption of the policy. In response to a critique of Quota System, he argues that its adoption was the first step in the right direction towards addressing the disparities in access to higher education. However, he proposes a more effective adaptation of the system to capture privilege and prestige which inform the social backgrounds, unlike the trajectory of 'districtisation' of the country followed in the current policy.

However, for some critics, the re-adoption of Quota System has its origins in regionalism. Shawa (2011) argues that by re-introducing the policy in 2009, the Malawi government sought to achieve narrow political aspirations based on regionalist logic. In reference to the 1987 modification of the policy, where admission to university became partially based on one's district of origin, he notes that 'the Malawi Congress Party government introduced a quota policy in selecting students to the University of Malawi based on district of origin and district population, which eventually disadvantaged the minority Tumbuka (predominantly resident in the northern region) speaking people's access to university education' (Shawa, 2011). As Sharra (2012) argues, the Quota System limits the admission of students from the northern region, who are believed to be 
disproportionately more than their counterparts in the central and southern regions. Similarly, Makwakwa (2009) argues that the University of Malawi under the direction of the executive believed that the merit-based system was unjust and contained some regional distortion.

Some scholars have even attributed Quota System to the birth of a new form of inequality where segregation is skewed towards those whose origins are districts that generally do well in secondary school national examinations. 'Msiska (2013) points out that due to the Quota System of selection, many students who pass well in national examinations but come from districts that usually perform well are left out for selection into higher classes' (Wamba \& Mgomezulu, 2014). They argue that instead, 'students who have not passed as well but come from preferred districts are selected' (p.328). Similarly, Nyondo (2016) raises another concern: Quota System still disadvantages those with a low socio-economic background, regardless of their district of origin. This is because the ten slots that are provided for each district in a public university are up for grabs by the best performing students of the districts, who are mostly from good schools where they were able to pay large sums for tuition - unaffordable for and inaccessible to the poor (Nyondo, 2016).

\section{$3 \quad$ Method}

This is a qualitative paper with a desk review of available literature on several aspects of the Equitable Access to Higher Education in Malawi. Due to scarcity of comprehensive scholarly literature, it relies on both scholarly and nonscholarly sources for data collection and analysis. The data that the paper relies on has been collected from academic journals, periodicals, announcements on public broadcasters in Malawi and discourses in various public forums that the author has participated in such as regular conversations and the social media. In addition to that, the article also relies on reports by different organizations in and outside Malawi. For a clear understanding of the concept, there is also a partial review of literature related to implementation of the Quota System from various countries around the world.

\section{What is the Equitable Access to Higher Education?}

For a starter, the Equitable Access to Higher Education is a type of affirmative action aimed at rectifying and eliminating discrepancies in access to higher education in Malawi. Affirmative action is an active effort to improve the employment or educational opportunities of members of minority groups and 
other vulnerable groups (Glum, 2018). Pertaining to access to higher education in Malawi, there have been other positive discrimination measures targeting the inclusion of more people with disabilities into the system as well as the reduction of gender disparity. Chivwara (2013) notices that government policies in Malawi demonstrate recognition of affirmative action to aid seven different vulnerable groups access higher education despite their different challenges. The groups include women, special needs students, geographical (regional/district) access disparities, low socio-economic status, students from rural backgrounds, orphans and the needy(Chivwara, 2013).To this regard, there have been several interventionist policies targeting these educationally disadvantaged groups.

In the discourses over selection into public universities, there have been various perspectives towards the notion of Equitable Access to Higher Education. While the public has often found it easier to refer to the policy as the Quota System, the University Council, the Ministry of Education, Science and Technology, and those in government have generally referred to the system with its official name, with a significant level of consistence: Equitable Access to Higher Education. This has a very significant implication. By consistent use of the term, government has evaded politicization of the policy through its own language politics. The term 'Quota System' is associated with a systemic hatred for the north due to the circumstances that surround the initial conception of the notion, culminating into political turmoil when a larger context and extension of the notion led to regionalization of deployment in the civil service in which teachers across Malawi were redeployed to their districts of origin in 1989. This followed allegations that northern teachers in other regions taught particularly badly in order that students from the central and southern regions should fail (Carver, 1994).

The Equitable Access to Higher Education is an affirmative action implemented against concerns of continued existence of disparities in admission into the public universities along geographical lines. Chivwara (2013) quotes Registrar of the University of Malawi who also doubles as a member of the University Council as saying 'Council began to think along the lines that, whilst the national cake is still small, if nothing is done about changing the current situation then you would have the same areas that have been documented in benefiting from higher education continue to do so' (p.89). According to the University Council, the affirmative action meant teach of the country's 30 districts would have ten spaces reserved for qualified students. Then, Blantyre, Lilongwe, Mzimba and Zomba districts would be classified into two zones namely urban and rural districts with each zone or category being guaranteed ten places (Chivwara, 2013). This is the case because Blantyre, Lilongwe and Zomba are not just districts - they are cities. And although Mzimba is just a district, it has a city located inside it namely Mzuzu. As such, these four districts have relatively higher populations than the rest, necessitating the need for the 
increased allocation. According to the explanation, the balance of the available places would be distributed on the basis of merit according to population ratios of district of origin.

The policy further stipulated that districts that could not contribute the guaranteed required minimum of ten qualified candidates would have the remaining places put into the general pool to be redistributed to other districts. This redistribution would be based on the equity system according to the population ratios of the districts concerned (Chivwara, 2013, pp. 89-90).

However, this is only in principle, as a policy. The reality is that the ten slots for each district are always filled. This explanation provides the contextual background of the policy's re-adoption sufficient enough to understand its motive from a technical and educational perspective. However, the justification behind the policy's re-implementation has not put to rest discussions over its existence in the public sphere. The policy has remained highly contentious, with both genuine arguments and deliberate distortions on both sides in the debates over its intention and assumed effectiveness.

\section{$5 \quad$ A Vehicle for Segregation? Criticism of the Policy}

The Equitable Access to Higher Education policy has remained under constant criticism from scholars, religious figures, educational and political activists among others in Malawi on the pretext that it is discriminatory. When a readoption of the policy was announced in 2009, there were protests and counterprotests by various sections of the public. A greater section of the critics believe that the system targets students from the northern region. The basis for this argument can be traced back to the origins of the policy during the one-party era when the University Registrar was reportedly overheard doubting the meritocracy of students from the north (Sharra, 2012). The sentiments were brought to the general public through a 1988 article in Chirunga Newsletter, a student magazine of one of the most influential constituent colleges of the University of Malawi, Chancellor College, which 'described how the chair of the University Council was overheard expressing his displeasure at "the large proportion of students from the north who enter the university," wondering whether they were admitted on merit or not' (Sharra, 2012). Sharra (2012) cites the article quoted in a memoir by Jack Mapanje - And the crocodiles are hungry at night - in which the Chirunga Newsletter article quotes the council chair as proceeding to suggest that a Quota System would be introduced at the beginning of the 1987 academic year in September where student selection into the University of Malawi would be on the basis of their district and region of birth (Sharra, 2012). The registrar's sentiments were representative of a bigger and 
influential political force that had the political power to execute the policy's implementation effectively - as had already been the case since the policy's actual introduction in 1969. This was President Banda's initiative, in what critics believe was a series of planned policies aimed at frustrating the north where most of his political opponents came from - a factor attributed to the colonial history of education. This has attracted labels to the former president as being 'antiintellectual, neo-patrimonial paternalist ideology of father and his "boys" or children; land owner and peasants; chief and his subjects; master and his servants, and President and his people...'(Mkandawire B. , 2010). The anti-northerner sentiments were confirmed when the government later redeployed all teachers from the north back to their region, arguing that they were deliberately not giving better education to students from the other regions (Carver, 1994).

However reasonable the justification of the policy can be, the nonchalance and arrogance in the manner in which the policy was presented to the public adversely contributed towards its outright rejection as discriminatory, regionalist and politically motivated by some sections. It was not presented with a mark of nobility through careful presentation of scientific or statistical facts to support the affirmative action and present a convincing argument in its favour to the public. Instead, authorities relied on political power to execute the implementation of the policy. The implementation was successful, but discontent with the policy from sections that were against it kept rising inwardly until in 1993 when some students contested the policy in court. The abolition of the system in 1993 through the juridical order and the ruling's subsequent upholding when government appealed in 2008 reaffirmed the logic behind the anti-quota sentiments, and reinvigorated the argument against the system. However, in 2009, President Bingu wa Mutharika took to the media providing a case for the re-introduction of the policy. This was again followed by court battles which resuscitated the debate on the system's merits and demerits. This, once again, put to question the discriminatory and patronizing tendency of politicians in their regionalist attitudes, with some critics like Shawa (2011) arguing that 'the policy represents the neo-patrimonial aspect of the patron-client relationship in which for example both state presidents who pushed for the policy (Banda and Mutharika), seem to have done so in a quest to make the majority happy for political gains' (p.171).

The court battles that have surrounded Quota System from its earlier inceptions represent another main challenge of the system that may be linked to discrimination: constitutionality of the policy. According to Banda (2012), the implementation of the policy has procedural and substantive aspects that are complex in view of constitutional obligations. For the earlier, the issue is whether the means for putting into practical operation the Equitable Access to Higher Education conforms to the requirements of the Malawi Constitution (Banda, 2012). For the latter, the issue is whether the type of equality remedy in the 
policy, and the design of the remedy, coincides with the type of equality remedies and the design of policies envisioned by the constitution of the Republic of Malawi. Banda (2012) argues that failure to take into account these concerns has the potential to derail the implementation of the policy on the basis that it is unconstitutional. This is what prompted the judicial review in 2009 on the policy, with the court finally upholding government's decision only on the grounds that those challenging it were not directly affected by the policy as was the case in 1993(Shawa, 2011).

The other main argument against the Equitable Access to Higher Education has been concerns that the system promotes mediocrity over meritocracy. Some sections have continuously expressed dissatisfaction with the system's university selection criteria arguing that giving priority first to top ten students in every district creates the risk of admitting low performing candidates from districts that have very few top performing students. This would be at the expense of districts where statistically students' performance in MSCE is mostly always high. Some critics have argued further that the system promotes laziness. In a letter addressed to the president in 2009, Harry Mkandawire, a Malawian politician, expressed such sentiments, demonstrating the perceptions some quarters have on the system.

In my view, the Quota System only serves to take away reward from welldeserving students. The system in the long-run will promote laziness because people will get the idea that they do not have to work hard because the government is going to take care of them (University World News, 2009).

A lot of other critics in various public forums have towed the lines of Mkandawire. At a cultural festival attended by the president of Malawi in 2015, Reverend Douglas Chipofya of the Church of Central African Presbytery's Livingstonia Synod asked government to abolish the Quota System, observing 'that students with better grades are left out in the selection process that aims to ensure equal distribution of university places across the country's three regions'(Nyirenda, 2015). The polarized opinions have resurfaced recently in a heated debate generated after the Vice President of Malawi on $21^{\text {st }}$ July, 2018, endorsed the abolition of the Equitable Access to Higher Education. In the follow-up debates on social media, some contributors reiterated Mkandawire's argument. One critic argued that the system 'only promotes ignorance and less hard working spirit in those who are assumed to be less intelligent' while another argued that 'there is no merit in selecting someone with 15 points from one district and leaving out someone with 13 points from another district'. To put the latter into perspective, achievement in the Malawi School Certificate of Education (MSCE) is indicated by grades 1 to 9 , of which grade 1 is the highest and grade 9 is the lowest. Candidates awarded grades 1 to 6 reach the equivalent standard of the General Certificate of Education (GCE) ordinary level pass in the United Kingdom. Grades 1 to 2 are distinctions; grades 3 to 6 are credits; grades 
7 and 8 are passes; and grade 9 is a fail. Candidates are awarded an MSCE if they either obtain a pass in six subjects, including English, with a credit in at least one of them, or pass five subjects including English, with a credit in at least three of them. As such, a candidate with the highest score in MSCE stands at 6 points (1, which is a distinction, in each of the six required subjects). Ideally, this means a 13 points MSCE certificate is stronger than a 15 points certificate.

The last main argument against Equitable Access to Higher Education is that it is perpetrating the same inequalities it is meant to redress, in a new form. Critics argue that a re-adoption of the policy has turned public university admission into a struggle between the 'haves' and 'have nots'. This argument posits that as true as it might be that the ten reserved places for each district are filled by deserving students, usually the students are from top schools where enrolment itself relies on a student's strong financial background. In an analysis on how Quota System is worsening inequalities, Nyondo (2016) assesses the plight of two boys, both from Chitipa district in northern Malawi. One attends a heavily under-resourced remote school where the highest performer in its MSCE history has only managed to score 29 points. The other attends a top tier boys' private secondary school in Blantyre City, Malawi's commercial capital. The differences between the two are enormous: from resource availability to exposure. However, much as their performance during MSCE examinations will reflect their different plights ideally through grade disparities, the Equitable Access to Higher Education will put them in a single basket during the selection process into university on the pretext that they are from the same district. The consequence is that because the first candidate's scores are poorer (often resulting from the nature of the school he attended) the selection process will favour the latter (Nyondo, 2016). To demonstrate the performance disparities between various schools, while by 2016 Wenya Community Day Secondary School in Chitipa had not produced a candidate with points better than 29 in MSCE examinations, a top tier very expensive school in Mzuzu city in the same northern region has a different story. In 2013 alone, Marymount Catholic Secondary School recorded 105 students out of 167 with points between 6 and 20 (Andiamo Trust, 2013). As such, those that go to under-resourced schools are at a disadvantage because their performance in MSCE often fails to grant them automatic entry into public universities through the top ten reserved slots for each district.

\section{A Different Perspective}

In the midst of the contentious debates over the policy's implementation, there is a need to explore more perspectives. The discourse must tilt towards acknowledging both the challenges and successes of the Equitable Access to 
Higher Education, often ignoring the flaring emotions and politics that have ruined moderate deliberations over the policy. However, the adoption of such a perspective requires acceptance of the need for affirmative action to aid the educationally disadvantaged access university education at the same rate as others. This leads to another challenge: acceptance that there is indeed an existence of geographical disparities in university enrolment, and that such disparities can be rectified through geographical quotas. Addressing concerns raised by sections against implementation of the Quota System is vital to unlocking this new discourse.

First, it must be acknowledged that where there is proof of social disparities rooted in historical or political situations (of which the system cannot alter), it becomes just to consider ways of rectifying the problem so the social injustice is brought to a halt. It is in this principle that countries such as USA, Brazil and India have found themselves implementing racial and caste quotas in their university admission processes as a better alternative affirmative action. When arguing for, or against implementation of the policy, it is imperative to include evidence of the existence of the geographical disparities in the country to see if it warrants such positive discrimination or not. There is scholarly evidence that proves that when the policy was made more stringent in 1987, Malawians from the north were generally at an advantage educationally because of the patterns of colonial education as the missionaries first established strong schooling systems in the north before moving to the other regions (Carver, 1994; Mkandawire, 2010).

For example, although the first mission was established in the Shire Highlands by the universities of Oxford and Cambridge under Bishop Mackenzie in the southern region in 1859, it withdrew in 1862 on account of loss of its members by sickness and other problems, only to be re-established much later in 1881 with its headquarters on Likoma island in the north. Before this re-establishment, another mission that was to become prominent and remains relevant in education to date was established in the country in 1874. The Livingstonia Mission, named after a famous Scottish explorer Dr. David Livingstone, was founded by the Free Church of Scotland, and located in the northern region too. These missionaries were joined by the Church of Scotland Mission in 1876, which chose the site of the present-day city of Blantyre and established themselves in the Shire Highlands (Colonial Reports - Annual, 1928). These missionaries were the pioneers of European form of education that has continued to date.

Now, schooling is a filial culture, it passes down from generation to generation through the family. 'There is consistent evidence that parents' education predicts children's educational outcomes, alongside other distal family characteristics such as family income, parents' occupations and residence location' (Eccles, 2005). Therefore, the colonial education pattern put feeder-communities to the missionaries' schools at an advantage, exposing Malawians in the north to 
colonial education earlier than their counterparts in the other two regions, and this heavily impacted access to higher education with time. As a result, as of 1987, Malawian students from the north constituted nearly 50\% of university entrants against the region's $12 \%$ of the total Malawian population (Mkandawire, 2010). The implication was a continued education pattern similar to the colonial establishment where one region would become dominant in technical expertise, often leading to other social stratification problems in occupation of various public and private offices - a recipe for public discontent in the long run.

While there is statistical evidence of regional underrepresentation in public universities necessitating the policy's adoption, statistics have begun showing that the policy is positively impacting equity in enrolment in universities. A study by the World Bank on UNIMA enrolment per 100,000 residents in each district for 2009 alone demonstrates significant variation between districts in enrolment. The districts of Neno, Ntcheu, Mwanza and Rumphi benefitted the most with 14 students per 100,000 residents drawn from each, while only 6 students were admitted from Lilongwe and Mzimba (Mambo et al, 2016).However, examination of enrolment data for 2010 demonstrates an improvement in the allocation of enrolment by district per 100,000 inhabitants, with the mean for admission from each district rising from 10 to 17 per 100,000 (Mambo et al, 2016). From the analysis, it is apparent that the policy is positively impacting the equitable distribution of enrolment across districts.

The other significant argument that must be carefully addressed relates to politicization of the public universities' admissions. As it has often been argued that the purging of Malawians from the north through the Quota System is also a means of advancing political agenda by various ruling parties (Shawa, 2011), there is need to establish truth in such sentiments. Mkandawire (2010) argues that the system's very adoption resulted from Dr. Banda's plan to frustrate the northern region which due to its higher levels of education harboured some of the most influential critics of his policies. This could be true considering the political climate during his era, from a 1964 cabinet crisis to his downfall in 1994. Further, there are postulations that Dr. Banda's anti-northern policies targeted appeasement of the majority of Malawians at the expense of the minority Malawians in the north for populism. The latter becomes a critical and seemingly more valid point when applied to the multi-party political dispensation of Malawi where leaders strive to impress the public for re-election into office. As such, when President Mutharika endorsed the Quota System too in 2009, the talk of political appeasement easily resurfaced (Shawa, 2011).

Although the theories around politicization of the policy might be valid, the critics often ignore the technical explanations behind the policy from the authorities responsible for its implementation. The politicization discourse has often been guided by political and tribal logic without any attempts at scrutinizing the policy from a technical perspective. The main challenge is that 
the policy has been hijacked by politicians and used as a campaign tool in convincing various audiences for political mileage. It has become fashionable, for example, when conducting political rallies in the northern region, to call for the abolition of the system without any explanation on the alternative measures in redressing the disparities the policy seeks to rectify. In USA, in the eight states where Quota System has been abolished, they have devised new alternative ways of dealing with the racial disparities in access to higher education (Desilver, 2014).The bottom line is the recognition of the existence of disparities, which the critics of Quota System tend to disregard, or relegate to insignificance. While some critics of the system have called for a widened access to higher education through the construction of more public universities, there is still no clear alternative on the short-term plans that would replace the system. But this may arise from the fact that they lack understanding of its origins, which is fuelled by the manner in which the policy has always been (re)adopted. During both the Banda and Mutharika regimes, it was simply imposed, without sufficient attempts to explain with factual and statistical proof to the public why the policy was justifiable - and for how long it would be in place until satisfactory expansion in access to university education was achieved.

\section{$7 \quad$ Addressing the Main Issues}

The criticism of the Equitable Access to Higher Education requires an in-depth analysis, followed by action. There is need for exploration of plausible and realistic solutions, both long-term and short-term. However, coming up with a long lasting solution is a challenge on its own because the main problem is financing. But government cannot evade its responsibility of making higher education as accessible as possible to everyone willing to pursue tertiary education while clinging to the principles of equity and justice. Reflections over this have led to various suggestions over the right course of action that government has to adopt. The suggestions range from abolition of the system as a whole to its modifications in the short-term while banking hopes on speedy public university constructions and expansions.

In the short term, as Mambo et al (2016) recommend, the priority should be in monitoring implementation and outcomes associated with this policy to ensure its ongoing contribution towards improved equitable access. This monitoring must go hand in hand with sensitization campaigns highlighting the benefits of the policy to the general public. Thus, there is need for transparency in explaining to the public on the selection procedure to clear doubts of regionalism in its implementation. A clear explanation, or availability of documents relaying the procedures to the public, would render ineffective the tendency of politicization 
of the issue. The vulnerability of people towards making uninformed decisions would be minimized, paving way to genuine debates on the merits and demerits of the policy.

Another short-term alternative is to skew the policy towards the social backgrounds of the students, not necessarily through districtisation. All districts have vulnerable families whose children fail to make it to top schools in spite of what statistics project about the overall levels of education in the different districts. As such, admitting students to universities based on their districts of origin still risks leaving the poor in the same spot they have always been, only this time with no interventionist policies to lift them out of their plight. This form of Quota System would be successfully implemented through 'profiling university graduates and current students in order to determine the legitimate population to benefit from this positive discrimination' (Kapito, 2016). However, the challenge with this is that it might still lead the discourse to the starting point again, where some sections of the society will still feel discriminated against. This is because through the same historical and colonial reality of the trends of education in Malawi, the social backgrounds of families originating from areas that had earlier exposure to colonial education remain advantaged as they pioneered working in the civil service in both the colonial and postcolonial governments. The trend continued through filial and generational influence.

In reforming the policy, there is also an argument for a possible adaptation of the system into one that targets school disparities. This relates to the argument of quotas on financial basis because the disparities in schools emanate from funding challenges. International schools, grant-aided schools, top tier private schools and other conventional government schools are well funded unlike the majority community day secondary schools. In turn, the top schools tend to send a lot of students to public universities since their MSCE performance is generally more satisfying. This is irrespective of their districts of origin. The rest either rot in the village or hustle for alternative post-secondary studies in private institutions or technical education. However, a setback with such a reform would be where in recognition of the odds of selection into university, wealthy students would try enrolling in the lowly ranked schools to beat the system, while at the same time enjoying a sufficient supply of materials funded by their families for study in their homes.

Cheating through the system is not uncommon. In the current system, candidates have been caught changing names and registering their origins in districts they perceive advantaged. In an interview with Times in 2016, one candidate who had cheated his way through said switching from a highlypopulated and competitive district to a less populated and less competitive one made it easier for one to get considered for admission into the universities (Times, 2016). The research by the news group had managed to identify three 
students from three secondary schools from all of the country's three regions who had changed not only their districts of origin but also surnames to stand a better chance of selection (Phiri, 2016).

The long-term solution for the system however rests in continuous expansion of capacity for public universities in Malawi. Government and the private sector must collaborate in expansion and construction of universities. Measures have already commenced, as can be observed through the construction of the Malawi University of Science and Technology which started its operations in 2014 and Nalikule College of Education which opened in 2017, the development of Bunda College of Agriculture into a full university (Lilongwe University of Agriculture and Natural Resources), the upgrading of Domasi College of Education, and now the construction of Mombela University as well as the unbundling of the University of Malawi which will evolve into four full universities, creating room for further expansion in the near future. However, the projects are not being implemented at the necessary speed, which renders them less useful when compared to the ever-increasing demand for university education in the country.

\section{Conclusion}

Disparities in access to higher education in Malawi are a reality. The inequity in the system has been reflected since the start of public university education in post-colonial Malawi, and continues to manifest itself. As the paper has established, the need for affirmative action through the Equitable Access to Higher Education continues to face enormous criticism from certain sections that feel segregated against. The paper also finds that this has been largely due to an improper implementation of the policy lacking sufficient awareness to the general public on matters relating to its complexities and significance. The paper has also noted that the discourse on the implementation of the policy is mostly hijacked by tribal and political reasoning, denting meaningful public engagement on the matter. However, the paper establishes the need to carefully examine the criticism and build from it solutions that are befitting to the betterment of the country's education system while at the same time not deviating from the human rights' principles of equity. In addition to the various recommendations on possible modification of the policy to eliminate some of the challenges, the paper strongly advocates for a better long term solution to the disparities, which is the expansion and construction of more public universities for an increased admissions capacity. The paper generally agrees with the need to maintain the Quota System as a necessary measure of redressing the current disparities, but it also endorses other critics' recommendations for an equity-oriented system that 
targets the disparities based on the socio-economic status of the candidates' families.

\section{References}

Andiamo Trust. (2013, November 19). Catholic Schools PSLCE, JCE, MSCE results impress ECM. Andiamo Youth Cooperative Trust.

Andrade, E. C. (2004). Quotas in Brazilian public universities: good or bad idea? Revista Brasileira de Economia, 58(4), 453-484.

Banda, S. (2012, September 6). Affirmative Action in the Publicly Funded Universities of Malawi: Unpacking the Role of Equality. The Nation.

Bhattacharyya, S., Woods, M., \& Lykes, M. B. (2017). Can educational policy redress historical discrimination? Exploring a university community's experiences with India's caste-based affirmative action policy. Community Psychology in Global Perspective, 3(2), 38-59.

Bowles, S., \& Gintis, H. (1976). Schooling in capitalist America: educational Reform and the contradictions of economic life. New York: Basic Books.

Brandão, A. A., \& Marins, M. T. (2007, January/April). Quotas for blacks in higher education and forms of racial classification. Educação e Pesquisa, $33(1)$.

Carver, R. (1994, May 1). Malawi: Between the Referendum and the Elections. Refiworld.

Castel, V., Phiri, M., \& Stampini, M. (2010). Education and employment in Malawi. Tunis: African Development Bank.

Chawinga, W. D., \& Zozie, P. A. (2016, June). Increasing access to Higher Education through Open and Distance Learning: Empirical findings from Mzuzu University, Malawi. International Review of Research in Open and Distributed Learning, 17(4), 1-20.

Chivwara, N. (2013). An analysis of the governance of higher education access in Malawi. Master's thesis, University of Western Cape, Department of Education.

CNN (2018, April 3). Affirmative action fast facts. https://edition.cnn.com/2013/11/12/us/affirmative-action-fastfacts/index.html.

Colonial Reports - Annual. (1928). Nyasaland Report for 1927. London: H.M. Stationery Office.

Deshpande, A. (2005). Affirmative action in India and the United States. World Development Report 2006.

Deshpande, A. (2012). Social justice through affirmative action in India: an assessment. In J. Wicks-Lim, \& R. Pollin (Eds.), Capitalism on Trial: 
Explorations in the Tradition of Thomas Weisskopf. Northamptom, MA: Edward Elgar Publishing Inc.

Desilver, D. (2014, April 22). Supreme Court says states can ban affirmative action; 8 already have. Pew Research Centre.

Drake, B. (2014, April 22). Public strongly backs affirmative action programs on campus. Pew Research Centre.

Eccles, J. S. (2005, November). Influences of parents' education on their children's educational attainments: the role of parent and child perceptions. London Review of Education, 3(3), 191-204.

Frye, M. (2012). Bright futures in Malawi's new dawn: Educational aspirations as assertions of identity. American Journal of Sociology, 117(6), 1565-1624.

Galafa, B. (2018, June). Secondary school admission and meritocracy: impacts of the tracking policy on education in Malawi. North American Academic Research, 1(1), 89-103.

Glum, J. (2018, July 18). Affirmative action in college admissions: everything you were too afraid to ask. Newsweek.

Hall, N., \& Mambo, M. (2015). Financing education in Malawi: Opportunities for action. Country Case Study for the Oslo Summit on Education for Development. Oslo: Oslo Education Summit.

Hoop, J. d. (2010). Selective secondary education and school participation in Sub-Saharan Africa: evidence from Malawi. Amsterdam: Tinbergen Institute.

Inoue, K., \& Oketch, M. (2008). Implementing free primary education in Malawi and Ghana: equity and efficiency analysis. Peabody Journal of Education, 83(1), 41-70.

Kapito, K. (2016, April 30). How quota system is worsening inequalities: a response. Malawi Nation.

Lee, V. E., \& Zuze, T. L. (2011). School resources and academic performance in Sub-Saharan Africa. Comparative Education Review, 55(3), 369-397.

Makwakwa, P. (2009, October 3). Equitable access to university education in Malawi: a social justice unicorn. http://nthambazale.com.

Mambo, M. M., Meky, M. S., Tanaka, N., \& Salmi, J. (2016). Improving higher education in Malawi for competitiveness in the global economy. Washington: World Bank.

Manyukwe, C. (2008, November 23). Malawi: Court bars controversial quota system. University World News (18).

Mkandawire, B. (2010). Ethnicity, language and cultural violence: Dr. Hastings Kamuzu Banda's Malawi, 1964-1994. The Society of Malawi Journal, 63(1), 23-42.

Mkandawire, M. T., Luo, Z., \& Maulidi, F. K. (2018). Does the UniversityIndustry Link Affect Solving Challenges of the Job Market? Lessons from Teacher Education and the Ministry of Education in Malawi. Journal of Medical Education and Curricular Development, 5, 1-9. 
Moran, R. F. (2006). Of doubt and diversity: the future of affirmative action in higher education. Ohio State Law Journal, 67, 201-243.

Msiska, M. (2015). Student satisfaction with university lecturers in Malawi: a case study of a private university. International Journal of Social Science and Humanities Research, 3(4), 582-589.

Msiska, M. (2016, October). Inside the Malawi government's policy to increase access to university education: A case study of the University of Malawi. International Journal of Research Studies in Management, 5(2), 39-49.

Mzuzu University. (2012). University Selection: 2011/2012 Intake for Generic Candidates. Mzuzu: http://www.sdnp.org.mw/edu/mzuni/mzuni-Admissionslist-2011-2012-Press-Release.pdf.

National Council for Higher Education. (2017). 2016/2017 UNIMA Intake. Zomba: University of Malawi.

Ng'ambi, F. (2010). Malawi: effective delivery of public education services. Johannesburg: Open Society Initiative for Southern Africa.

Nyirenda, V. (2015, August 9). Synod renews calls for Quota System abolition. Zodiak Malawi.

Nyondo, E. (2016, April 15). How quota system is worsening inequality. Malawi.

Phiri, D. D. (2016, March 2016). On the youth week, chiefs and quota system. Times.

Sabbagh, D. (2011). Af $1 / 2$ rmative Action: The U.S. experience in comparative experience. Journal of the American Academy of Arts \& Sciences, 140(2), 109120.

Santos, J. T., \& Queiroz, D. M. (2016). The Impact of the "Quota System" in the Federal University of Bahia (2004-2012). Creative Education, 2678-2695.

Sharra, S. (2012, November 11). Illusions of elite entitlement: Quota \& Malawi's higher education access woes. Afrika aphukira.

Shawa, L. B. (2011). Exploring anti-democratic practices in university policysteerage, management and governance in Malawi: a critical theory approach. PhD thesis. Victoria University of Wellington.

Telle, E., \& Paixão, M. (2013). Affirmative action in Brazil. LASAFORUM, 44(2), 10-12.

Times. (2016, March 19). Students cheat quota system. Times.

University World News. (2009, December 13). Malawi: politician arrested over quotas. University World News (43).

University World News. (2010, January 31). Malawi: court backs controversial quotas. University World News (46).

Valeta, J., Sefasi, A., \& Kalizang'oma, R. (2016). Status of Higher Education, Science and Technology in Malawi: A focus on Agricultural Higher Education. African Journal of Rural Development, 1(2), 179-192.

Wamba, N., \& Mgomezulu, V. (2014, April). The crisis in public education in Malawi. International Journal of Advanced Research, 2(4), 323-331. 
Wamba, N., \& Mgomezulu, V. (2014). The crisis in public education in Malawi. International Journal of Advanced Research, 2(4), 323-331.

Wilber, C. (1984). The Political Economy of Development and Underdevelopment (3rd Ed.). New York: Random House.

World Data on Education. (2011). Malawi. Lilongwe: UNESCO. 